\title{
Alpha4 chain laminins are widely expressed in renal cell carcinomas and have a de-adhesive function
}

\author{
Noora Vainionpää ${ }^{1}$, Veli-Pekka Lehto², Karl Tryggvason ${ }^{3}$ and Ismo Virtanen ${ }^{1}$
}

Laminin ( $\mathrm{Lm}) \alpha 4$ chain, a constituent of $\mathrm{Lm}-411$ and $\mathrm{Lm}-421$, is mainly localized to mesenchyme-derived tissues, and is suggested to have a role in formation and function of endothelium, transmigration of inflammatory cells through endothelium, and invasion of certain tumors. In this study, we evaluated the distribution of $\alpha 4$ chain Lms in 33 conventional (clear cell) renal cell carcinomas (RCCs) (31 primary tumors, two metastases), two papillary RCCs, and two oncocytomas by immunohistochemistry. In all tumors, immunoreactivity for $\mathrm{Lm} \alpha 4$ chain was found in vasculature and stroma. Basement membranes were detected around tumor cell islets in 34/37 tumors. They showed immunoreactivity for $\mathrm{Lm} \alpha 4$ chain in 28/34 cases. Northern blotting, inhibition of protein secretion with monensin, and immunoprecipitation combined with Western blotting showed that Caki-2, ACHN, and Caki-1 renal carcinoma cell lines produce $\alpha 4$ chain Lms. In cell adhesion assay, recombinant human Lm-411 did not promote adhesion of renal carcinoma cells but inhibited adhesion to fibronectin (Fn). In cell migration assay, the cells migrated more on Lm-411 than on Fn. The results suggest that $\alpha 4$ chain Lms have a de-adhesive function and could thus play a role in detachment, migration and invasion of renal carcinoma cells in vivo.

Laboratory Investigation (2007) 87, 780-791; doi:10.1038/labinvest.3700592; published online 28 May 2007

KEYWORDS: $\alpha 4$ chain; adhesion; basement membrane; laminin; renal cell carcinoma

Renal carcinomas account for approximately $2 \%$ of new cancer cases and $1.5 \%$ of cancer deaths globally. ${ }^{1}$ According to the most recent classification of renal tumors, vast majority (approximately 70\%) of malignant renal tumors are conventional (clear cell) renal cell carcinomas (RCCs). Other malignant tumor types are papillary RCCs, chromophobe RCCs, collecting duct carcinomas, and unclassified RCCs. Benign tumors include renal oncocytomas, papillary adenomas, and metanephric adenomas. ${ }^{2-4}$

Carcinomas can be viewed as diseases of disrupted tissue architecture and abnormal cell-extracellular matrix interactions. Basement membranes (BMs), specialized sheets of extracellular matrix found at the epithelial-mesenchymal interface, encircling endothelia and certain types of isolated cells, seem to be critical control elements in carcinogenesis., In addition to maintaining tissue architecture, BMs function as selectively permeable barriers for macromolecules ${ }^{7}$ and cells. ${ }^{8}$ Interactions of BM constituents with cell surface receptors influence cytoskeletal organization and intracellular signaling, and thereby regulate various cell functions, in- cluding attachment, differentiation, polarization, proliferation, survival, and motility. ${ }^{6,9}$

The core of BM consists of independent networks of laminins (Lms) and type IV collagens bound together by nidogens. ${ }^{9,10}$ Developmental studies have demonstrated the essential role of Lms in BM assembly. ${ }^{9}$ Lms are a family of at least 15 heterotrimeric, cruciform or T-shaped glycoproteins, each formed by one of the five $\alpha$, three $\beta$ and three $\gamma$ chains. ${ }^{9,11,12}$ Lms, especially the Lm $\alpha$ chains, have developmentally regulated and tissue-specific distributions, and confer structural and functional diversity to BMs. ${ }^{9}$

Our previous studies on RCCs have shown the presence of $\alpha 1$ chain Lms in stroma and BMs of tumor cell islets. ${ }^{13} \alpha 3$ chain-containing Lm-332 is found in papillary RCC and oncocytomas, and $\alpha 5$ chain Lms are widely expressed in RCCs and oncocytomas. On the other hand, $\alpha 2$ chain Lms are not found in renal tumors. ${ }^{14}$ In several microarray studies comparing gene expression of renal tumors with that of normal kidneys, however, $\operatorname{Lm} \alpha 4$ chain has been found to be the only $\operatorname{Lm} \alpha$ chain overexpressed in renal tumors. ${ }^{15-18}$

\footnotetext{
${ }^{1}$ Institute of Biomedicine/Anatomy, University of Helsinki, Helsinki, Finland; '²Department of Pathology, Haartman Institute, University of Helsinki, Helsinki, Finland and ${ }^{3}$ Department of Medical Biochemistry and Biophysics, Division of Matrix Biology, Karolinska Institutet, Stockholm, Sweden

Correspondence: Dr N Vainionpää, MD, Institute of Biomedicine/Anatomy, University of Helsinki, PO Box 63 (Haartmaninkatu 8), Fl-00014 Helsinki, Finland.

E-mail: noora.vainionpaa@helsinki.fi
}

Received 20 March 2007; revised 23 April 2007; accepted 30 April 2007 
Lm $\alpha 4$ chain, a constituent of Lm-411 and Lm-421, is found in tissues of mesenchymal origin, in endothelial BMs, and in certain epithelial BMs. ${ }^{19-21}$ It seems to promote migration and survival of endothelial cells, ${ }^{22-24}$ migration and proliferation of blood cells, ${ }^{25,26}$ and transmigration of inflammatory cells through endothelium. ${ }^{8}$ Deletion of $\mathrm{Lm} \alpha 4$ chain gene in mice impairs vascular development, and leads to cardiomyopathy, demyelinating neuropathy, and increasing tumor neovascularization and metastasis. ${ }^{27-30}$ Overexpression of $\mathrm{Lm} \alpha 4$ chain, on the other hand, has been suggested to promote angiogenesis, ${ }^{31,32}$ and to correlate with malignancy and invasive capacity in human gliomas. ${ }^{3-36}$ Tissue-specific inhibition of $\operatorname{Lm} \alpha 4$ chain expression with antisense oligonucleotides has been suggested to be a potential new treatment for gliomas and tumor angiogenesis. ${ }^{32,37}$ The role of $\alpha 4$ chain Lms in carcinomas has remained largely unresolved. ${ }^{38,39}$ Therefore, we set out to study the distribution of $\alpha 4$ chain Lms in RCCs and their production by RCC cells. We also evaluated the potential functional consequences of $\mathrm{Lm} \alpha 4$ chain expression in RCCs by studying the effect of recombinant human Lm-411 on adhesion and migration of cultured RCC cells.

\section{MATERIALS AND METHODS}

\section{Tissues}

RCCs $(n=33)$, RCC metastases $(n=2)$, and oncocytomas $(n=2)$ were obtained from nephrectomies performed at the Jorvi Hospital (Espoo, Finland) and at the Oulu University Central Hospital (Oulu, Finland), frozen in liquid nitrogen, stored in $-70^{\circ} \mathrm{C}$, and retrieved from the files of Institute of Biomedicine/Anatomy. The tumors were classified and graded by a pathologist. ${ }^{14,40}$ This was originally performed according to the WHO criteria. ${ }^{41,42}$ For the purposes of the present study, a reclassification was performed according to the Heidelberg/Rochester classification. ${ }^{2-4}$ The tumors included 31 conventional (clear cell) RCCs (10 grade 1, 15 grade 2, and six grade 3 ), two metastases of conventional RCCs (one grade 1 and one grade 3), two papillary RCCs (two grade 1), and two oncocytomas.

\section{Cultured Cells}

Three RCC cell lines, Caki-2 isolated from clear cell RCC, ACHN isolated from malignant pleural effusion of patient with metastatic renal adenocarcinoma, and Caki-1 isolated from cutaneous metastasis of clear cell RCC were obtained from the American Type Culture Collection (Manassas, VA, USA). We have previously shown that, when injected subcutaneously in nude athymic mice, Caki-2 cells form well differentiated clear cell grade 1 tumors, whereas ACHN and Caki-1 cells form poorly differentiated grade 3 tumors. ${ }^{43}$ The cells were cultured in RPMI 1640 medium (Cambrex Bioscience, Verviers, Belgium) with 10\% fetal bovine serum (Perbio Science, Erembodegem, Belgium) and antibiotics.

Human dermal microvascular endothelial (HDME) cells, used as positive controls in immunoprecipitation and
Western blotting, were obtained from PromoCell (Heidelberg, Germany), and cultured in Endothelial Cell Growth Medium-2 MV (EGM-2 MV; PromoCell).

\section{Immunohistochemistry}

For immunohistochemistry, we used mouse monoclonal antibodies (MAbs) $168 \mathrm{FC} 10$ to human $\mathrm{Lm} \alpha 4$ chain, ${ }^{21}$ 114DG10 to human $\operatorname{Lm} \beta 1$ chain, ${ }^{44}$ S5F11 to human $\operatorname{Lm} \beta 2$ chain, ${ }^{45}$ and $113 \mathrm{BC} 7$ to human $\mathrm{Lm} \gamma 1$ chain, ${ }^{46}$ as well as affinity-purified rabbit antiserum to $\mathrm{Lm} \alpha 1$ chain. ${ }^{47}$ Tetramethylrhodamine isothiocyanate-coupled Ulex europaeus-I agglutinin (TRITC-UEA-I; Vector Laboratories, Burlingame, CA, USA) was used to identify blood vessel endothelia. ${ }^{48}$ Cells grown on glass coverslips were fixed in methanol at $-20^{\circ} \mathrm{C}$ for $15 \mathrm{~min}$. For inhibition of protein secretion, cells were exposed to $5 \mu \mathrm{M}$ monensin (Sigma, St Louis, MO, $\mathrm{USA}^{49}$ ) for $16 \mathrm{~h}$ before fixation. The snap-frozen tissues were cut to $6-7 \mu \mathrm{m}$ sections and fixed in acetone at $-20^{\circ} \mathrm{C}$ for $10 \mathrm{~min}$.

For light microscopy, the fixed cryosections were first exposed to MAbs, and the bound antibodies were then visualized with the alkaline phosphatase-anti-alkaline phosphatase method (APAAP mouse monoclonal, DAKO, Glostrup, Denmark), and by applying a substrate solution containing $\mathrm{NaNO}_{2}$ (Merck, Darmstadt, Germany), New Fuchsin (Sigma), levamisole (Sigma), naphthol AS-BI phosphate (Sigma), and dimethylformamide (Merck). The sections were counterstained with Mayer's hematoxylin (Merck), mounted in Eukitt $^{\mathbb{R}}$ (O Kindler, Freiburg, Germany), and examined under Olympus AX70 microscope (Olympus, Tokyo, Japan) equipped with a digital camera. For immunofluorescence microscopy, the specimens were first exposed to MAbs, followed by Alexa Fluor 488 goat anti-mouse IgG (Molecular Probes, Eugene, OR, USA). For double labeling, the specimens were then exposed either to affinity-purified rabbit antiserum to $\mathrm{Lm} \alpha 1$ chain and Alexa Fluor 568 goat antirabbit IgG (Molecular Probes), or to TRITC-UEA-I. The specimens were embedded in sodium veronal-glycerol buffer ( $\mathrm{pH}$ 8.4) or polyvinylalcohol mounting medium, and examined under a Leitz Aristoplan microscope (Leica Microsystems, Wetzlar, Germany) equipped with appropriate filters. For laser scanning confocal microscopy, a Leica TCS SP2 system (Leica Microsystems) and argon and krypton laser excitation lines $488 \mathrm{~nm}$ and $568 \mathrm{~nm}$ were used. Image stacks were collected using sequential scanning through the sections using optimized $366 \mathrm{~nm} z$-sampling density. The results are shown as maximum intensity projections of four section stacks. Negative controls, in which the primary antibodies were omitted, lacked immunoreactivity.

\section{Northern Blotting}

Northern blotting was performed with digoxigenin-labeled RNA probes, using DIG Nonradioactive Nucleic Acid Labeling and Detection System by Roche (Mannheim, Germany), according to the manufacturer's instructions. A pBluescript plasmid vector (Stratagene, La Jolla, CA, USA), 
comprising 2714 nucleotides of human $\operatorname{Lm} \alpha 4$ chain, was created as previously described $\left(\mathrm{HL} 4-5^{\prime 50}\right)$. An antisense RNA probe was created first by linearizing with EcoRI (Sig$\mathrm{ma}$ ) and then introducing a digoxigenin label simultaneously with in vitro transcription, using DIG RNA Labeling kit (SP6/T7) (Roche) and T7 RNA polymerase (Roche).

Total RNA was isolated from RCC cells by using Eurozol (EuroClone, Milano, Italy), and poly(A) ${ }^{+}$RNAs were enriched by using Dynabeads ${ }^{\circledR}$ Oligo $(\mathrm{dT})_{25}$ beads (Dynal, Oslo, Norway). The RNA was separated according to size on a denaturing $1.2 \%$ agarose gel and transferred onto Nylon Membranes, Positively Charged (Roche), by upward capillary transfer. Northern hybridization was performed by using DIG Easy Hyb Granules (Roche). Prehybridization was carried out at $68^{\circ} \mathrm{C}$ for $30 \mathrm{~min}$, and hybridization was carried out at $68^{\circ} \mathrm{C}$ for $16 \mathrm{~h}$. The hybridized probes were detected with antidigoxigenin-AP conjugate (Roche) and CSPD, ready-to-use (Roche). The blots were then exposed to Hyperfilm MP (Amersham Biosciences, Uppsala, Sweden). For reuse of the blots, the previously detected probes were erased by pouring boiling $0.1 \%$ sodium dodecyl sulfate (SDS) on the filter, according to the instructions by Roche. Hybridization with an antisense RNA probe to glutaraldehyde-3-phosphatedehydrogenase (GAPDH) was used as a loading control, and hybridization with a sense RNA probe to $\operatorname{Lm} \alpha 4$ chain was used as a negative control (not shown). As size markers, we used RNA molecular weight marker I, digoxigenin labeled (0.3-6.9 kb) (Roche).

\section{Immunoprecipitation and Western Blotting}

For immunoprecipitation experiments, the culture media of Caki-2, ACHN, Caki-1, and HDME cells were first cleared by centrifugation, and then supplemented with Triton X-100 $(0.5 \%)$ and normal mouse serum. The supernatant was preabsorbed with GammaBind ${ }^{\mathrm{TM}}$ Plus Sepharose ${ }^{\mathrm{TM}}$ beads (Amersham Biosciences), and subsequently applied onto GammaBind $^{\mathrm{TM}}$ Plus Sepharose ${ }^{\mathrm{TM}}$ beads precoupled with MAb $113 \mathrm{BC} 7$ to $\operatorname{Lm} \gamma 1$ chain. ${ }^{46}$ The bound proteins were eluted with Laemmli's reducing sample buffer and separated by SDS polyacrylamide gel electrophoresis on $5 \%$ gels. For Western blotting the samples were transferred onto nitrocellulose filters, after which the filters were blocked using 5\% dry milk in phosphate-buffered saline (PBS). The filters were subsequently exposed to rabbit antiserum to $\operatorname{Lm} \alpha 4$ chain. ${ }^{51}$ Immunoreactive bands were visualized using horseradish peroxidase-coupled anti-rabbit immunoglobulins (DAKO) with SuperSignal ${ }^{\mathbb{R}}$ West Pico Chemiluminescent Substrate (Pierce, Rockford, IL, USA), according to the manufacturers' instructions. As size markers, we used Standard Mixture for Molecular Weights 30000-200000 for SDS polyacrylamide gel electrophoresis (Sigma).

\section{Cell Adhesion Assay}

Quantitative cell adhesion assays were performed using a method based on intracellular acid phosphatase. ${ }^{52}$
Recombinant human Lm-411 was produced in a mammalian expression system, as previously described. ${ }^{53}$ Fibronectin (Fn) was purified from outdated human plasma (Finnish Red Cross Blood Transfusion Service, Helsinki, Finland) by Gelatin Sepharose $^{\mathrm{TM}}$ 4B affinity chromatography (Amersham Biosciences), according to Engvall and Ruoslahti. ${ }^{54}$ Ninetysix-well plates were coated with $1-20 \mu \mathrm{g} / \mathrm{ml}$ recombinant human Lm-411 and/or Fn in PBS at room temperature for $1 \mathrm{~h}$, washed twice with PBS, treated with $3 \%$ bovine serum albumin in PBS at room temperature for $1 \mathrm{~h}$, and washed again twice with PBS. In order to avoid interference of de novo protein secretion during the experiment, cycloheximide was added $(10 \mu \mathrm{g} / \mathrm{ml}$; Sigma) to the culture medium of the cells $1 \mathrm{~h}$ before the cells were plated. ${ }^{55}$ It was also included to washing and adhesion media. The cells were detached from the culture plates using trypsin and EDTA, exposed to a trypsin-neutralizing solution (PromoCell), and washed with the adhesion medium (RPMI 1640 without fetal bovine serum). The cells were plated at $2 \times 10^{4}$ cells per well and incubated at $37^{\circ} \mathrm{C}$ in $5 \% \mathrm{CO}_{2}$ for $1 \mathrm{~h}$. The wells were carefully washed to remove non-adherent cells. Substrate solution (Sigma 104 phosphatase substrate $6 \mathrm{mg} / \mathrm{ml}$ in $50 \mathrm{mM}$ sodium acetate buffer with $0.1 \%$ Triton X-100, $\mathrm{pH} 5$ ) was added to each well and the plates were incubated at $37^{\circ} \mathrm{C}$ for $1 \mathrm{~h}$. The reaction was stopped with $1 \mathrm{M} \mathrm{NaOH}$ and the absorbances were measured at $405 \mathrm{~nm}$. Bovine serum albumin-coated wells were used as controls. Experiments were performed in triplicate, and the absorbances were expressed \pm s.d. of three wells. The difference between two variables was tested with a two-sided, unpaired $t$-test with a significance level of $\alpha=0.05$.

\section{Cell Migration Assay}

Undirected random migration ${ }^{56}$ of RCC cells on extracellular matrix proteins was studied by fluorescence live cell imaging (method modified from 24). First, glass bottom culture dishes (MatTek Corporation, Ashland, MA, USA) were coated with either $5 \mu \mathrm{g} / \mathrm{ml}$ recombinant human $\mathrm{Lm}-411$ or $5 \mu \mathrm{g} / \mathrm{ml} \mathrm{Fn}$ in PBS at room temperature for $1 \mathrm{~h}$, washed twice with PBS, treated with $3 \%$ bovine serum albumin in PBS at room temperature for $1 \mathrm{~h}$, and washed twice with PBS. The cells were labeled with $20 \mu \mathrm{M}$ of CellTracker ${ }^{\mathrm{TM}}$ Green CMFDA (Molecular Probes) for $30 \mathrm{~min}$, according to the manufacturer's instructions. The cells were detached with trypsin and EDTA, exposed to a trypsin-neutralizing solution (PromoCell), washed with experiment medium (phenol red-free DMEM, Gibco, Invitrogen, Paisley, UK), and plated onto coated dishes ( $10^{5}$ cells in $2 \mathrm{ml}$ medium). The cells were allowed to attach at $37^{\circ} \mathrm{C}$ in $5 \% \mathrm{CO}_{2}$ for $15 \mathrm{~min}$ before imaging. Fluorescence live cell imaging was performed with T.I.L.L. Photonics Multi-Color Ratio Imaging System (TILL Photonics GmbH, Munich, Germany) based on Olympus IX-70 inverted microscope and TILLvisION software v. 4.01 (TILL Photonics), by exposing the cells for $15 \mathrm{~ms}$ to $492 \mathrm{~nm}$ monochromatic light in every $30 \mathrm{~s}$ for $2 \mathrm{~h}$ under cell culture 
conditions $\left(37^{\circ} \mathrm{C}, 5 \% \mathrm{CO}_{2}\right)$, and observed with $\times 10$ objective and over $520 \mathrm{~nm}$ emission filter. The trajectories of the cells were analyzed with ImageJ 1.37 c (Rasband WS: Image J, National Institutes of Health, Bethesda, MD, USA, http:// rsb.info.nih.gov/ij/, 1997-2004) and MTrack2 plugin. ${ }^{57}$ The experiments were performed in triplicate. Migration on each coat was expressed as average, median, and \pm s.d. of total length of the migration trajectories of all cells found in all images of a microscope field (in average 65 cells/field) of a representative experiment. The difference between two variables was tested with a two-tailed Mann-Whitney $U$-test with a significance level of $\alpha=0.05$.

\section{RESULTS}

\section{$\alpha \mathbf{4}$ Chain Lms in RCCs}

First we evaluated the localization of $\mathrm{Lm} \alpha 4$ chain in renal tumors by immunohistochemistry with APAAP technique and light microscopy. In oncocytomas, immunoreactivity for $\mathrm{Lm} \alpha 4$ chain was found in the BM region around tumor cell islets, in capillaries (Figure 1a), and in the region of endothelial BMs of larger blood vessels (not shown). Stromal areas between the tumor cell islets showed only traces of immunoreactivity for Lm $\alpha 4$ chain (Figure 1a), whereas stromal areas around larger blood vessels showed prominent immunoreactivity (not shown).

In all RCCs representing primary tumors of grade 1-3 conventional RCCs (Figure 1b-d), in metastases of grade 1 and 3 conventional RCCs (Figure 1e), and in primary tumors of grade 1 papillary RCCs (Figure 1f), immunoreactivity for $\operatorname{Lm} \alpha 4$ chain was found in capillaries, in the region of endothelial BMs of larger blood vessels (not shown), and in stroma. Due to the continuous nature of the staining, the immunoreactivity of $\mathrm{BM}$ region around tumor cell islets could not be with certainty distinguished from the immunoreactivity of the stroma and endothelial BMs.

In order to make the separation between immunoreactivity for Lm $\alpha 4$ chain in BMs of endothelia, BMs of tumor cell islets, and stroma, we continued the study by double-labeling immunofluorescence microscopy. The results are summarized in Table 1 . To evaluate the presence of $\operatorname{Lm} \alpha 4$ chain in BMs of tumor cell islets, we explored its colocalization with Lm $\alpha 1$ chain. This was based on our previous studies, which show that $\mathrm{Lm} \alpha 1$ chain is typical for epithelial $\mathrm{BMs},{ }^{58}$ and is also found in RCCs in BMs of tumor cell islets. ${ }^{13}$ Linear Lm $\alpha 1$ chain-immunoreactive BMs were found around tumor cell islets in $2 / 2$ oncocytomas, $10 / 10$ grade $1,14 / 15$ grade 2 , and 4/6 grade 3 conventional RCCs, 2/2 metastases of conventional RCCs, and 2/2 papillary RCCs. Among these tumors with $\mathrm{Lm} \alpha 1$ chain-immunoreactive BMs, Lm $\alpha 4$ chain immunoreactivity was found in colocalization with $\mathrm{Lm} \alpha 1$ chain immunoreactivity in $2 / 2$ oncocytomas, $7 / 10$ grade 1 , 12/14 grade 2, 4/4 grade 3 conventional RCCs, 2/2 metastases of conventional RCCs, and 1/2 papillary RCCs, as exemplified by laser scanning confocal microscopy (Figure 1g-i, metastasis of grade 3 conventional RCC, others not shown).
As further evidence for the presence of $\operatorname{Lm} \alpha 4$ chain immunoreactivity in blood vessel endothelial BMs, we studied its colocalization with reactivity for endothelial marker TRITC-UEA-I. As exemplified by laser scanning confocal microscopy, immunoreactivity for $\operatorname{Lm} \alpha 4$ chain was found in contact with TRITC-UEA-I-reactive endothelia in all tumors (Figure $1 \mathrm{j}-1$, grade 2 conventional RCC, others not shown).

In our previous studies we have examined the distribution of $\operatorname{Lm} \beta 1, \beta 2$, and $\gamma 1$ chains, the other constituents of $\alpha 4$ chain Lm-411 and Lm-421, in RCCs. Lm $\beta 1$ and $\gamma 1$ chains are widely distributed to BMs of oncocytomas and all RCCs. Lm $\beta 2$ chain is found in BMs of oncocytomas and conventional RCCs. ${ }^{14}$ Recently in has been suggested that there would be a shift from the expression of Lm-421 to Lm-411 during progression of malignancy in glioma and breast carcinoma. ${ }^{33,34,38}$ Therefore, we re-evaluated with different MAbs the expression of $\operatorname{Lm} \beta 1, \beta 2$, and $\gamma 1$ chains in a subset of our specimens, including two oncocytomas, three grade 1, three grade 2, and three grade 3 conventional RCCs, two metastases of conventional RCCs, and two papillary RCCs.

In $2 / 2$ oncocytomas, $3 / 3$ grade $1,2 / 3$ grade 2 , and $3 / 3$ grade 3 conventional RCCs, and 2/2 metastases of conventional RCCs, $\operatorname{Lm} \beta 1, \beta 2$, and $\gamma 1$ chains were found in the BMs of blood vessels, the BMs of tumor cell islets, and in stroma. Lm $\alpha 4$ chain was present in the same locations (Figure 2a-d, metastasis of grade 3 conventional RCC, others not shown). $\operatorname{Lm} \beta 2$ chain immunoreactivity was not found in the BMs of tumor cell islets in $1 / 3$ grade 2 conventional RCC. In this tumor, the BMs of tumor cell islets were also devoid of immunoreactivity for $\mathrm{Lm} \alpha 4$ chain (not shown). In $2 / 2$ papillary RCCs, $\operatorname{Lm} \beta 1$ and $\gamma 1$ chains were found in the BMs of blood vessel, stroma, and the BMs of tumor cell islets (not shown). Lm $\beta 2$ chain was only found in the BMs blood vessels but not in the stroma or the Lm $\alpha 1$ chain-immunoreactive BMs of tumor cell islets (Figure 2e and $\mathrm{f}$ ). Thus, based on the localization of the constituent Lm chains, $\mathrm{Lm} \alpha 4$ chain could be a constituent of both Lm-411 and Lm421 in conventional RCCs. In papillary RCCs, constituents of $\mathrm{Lm}-411$ were found in stroma and in some tumors in BMs of tumor cell islets, whereas constituents of both Lm-411 and Lm-421 were found in blood vessels.

\section{Production of $\alpha \mathbf{4}$ Chain Lms by RCCs}

The aforementioned results on the presence of $\mathrm{Lm} \alpha 4$ chain in BMs of tumor cell islets suggested that $\mathrm{Lm} \alpha 4$ chain could be produced by RCC cells. Therefore, we also studied its synthesis by RCC cell lines.

Northern blot analysis of RNA extracted from Caki-2, ACHN, and Caki-1 RCC cells (Figure 3) showed an Lm $\alpha 4$ chain transcript of approximately $6.5 \mathrm{~kb}$. The expression was weakest in Caki- 2 cells and strongest in Caki- 1 cells.

In immunofluorescence microscopy, RCC cells grown under normal cell culture conditions showed only a weak, uniform cytoplasmic immunoreactivity for $\mathrm{Lm} \alpha 4$ chain (not 

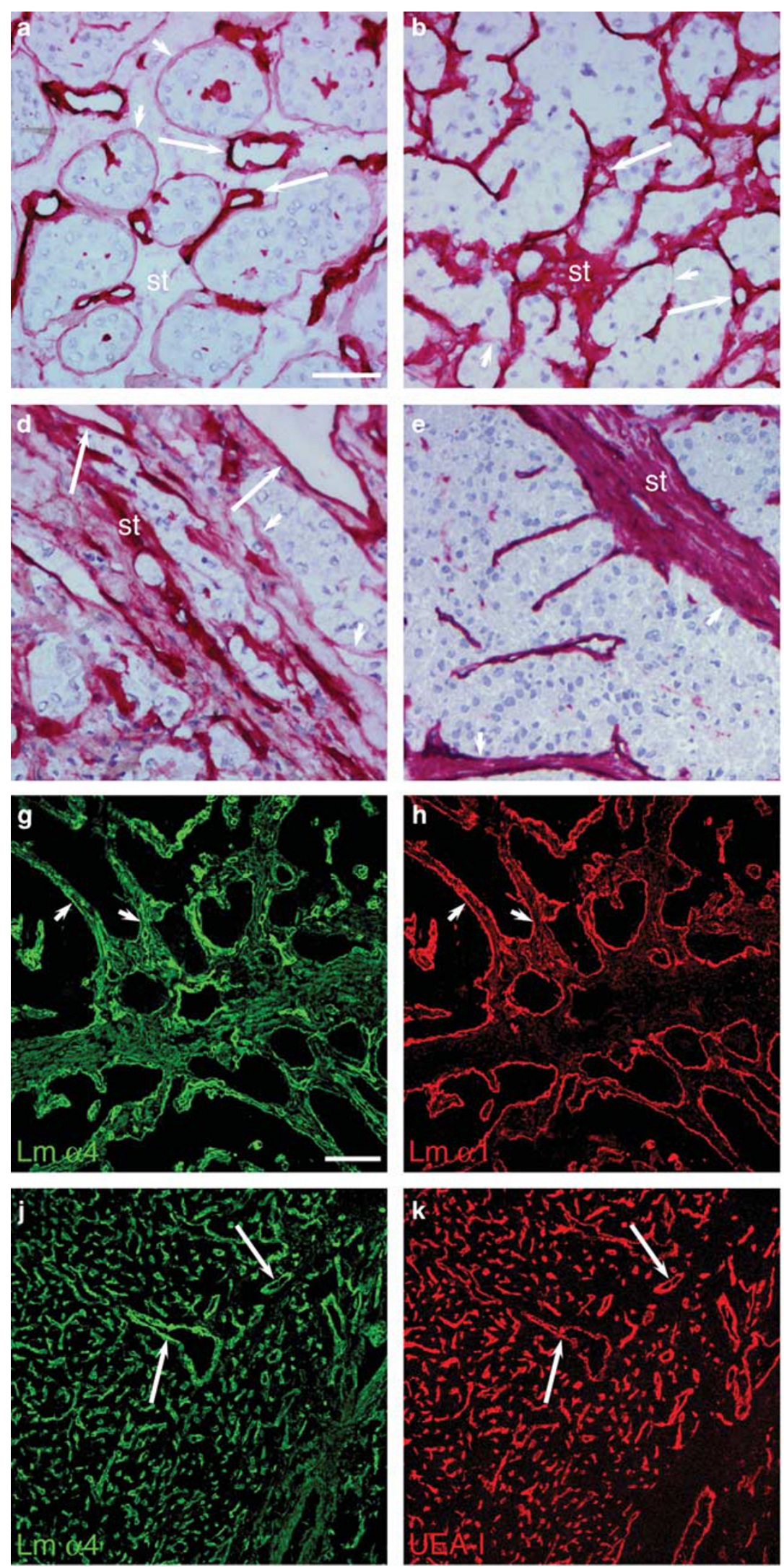
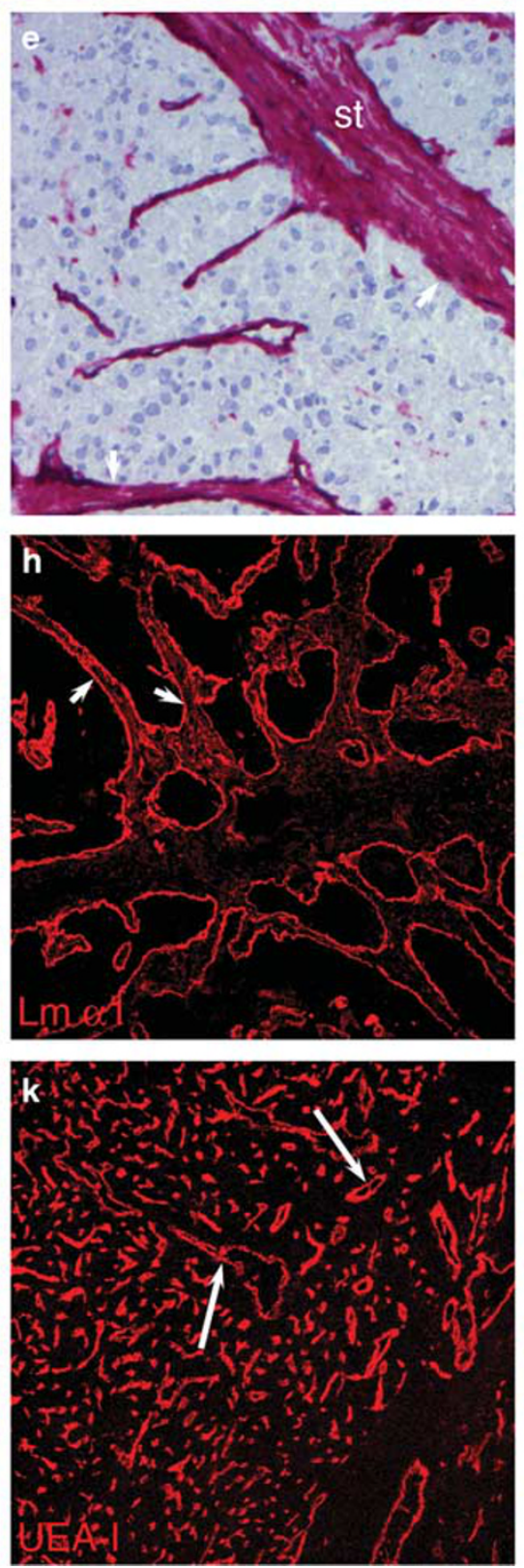
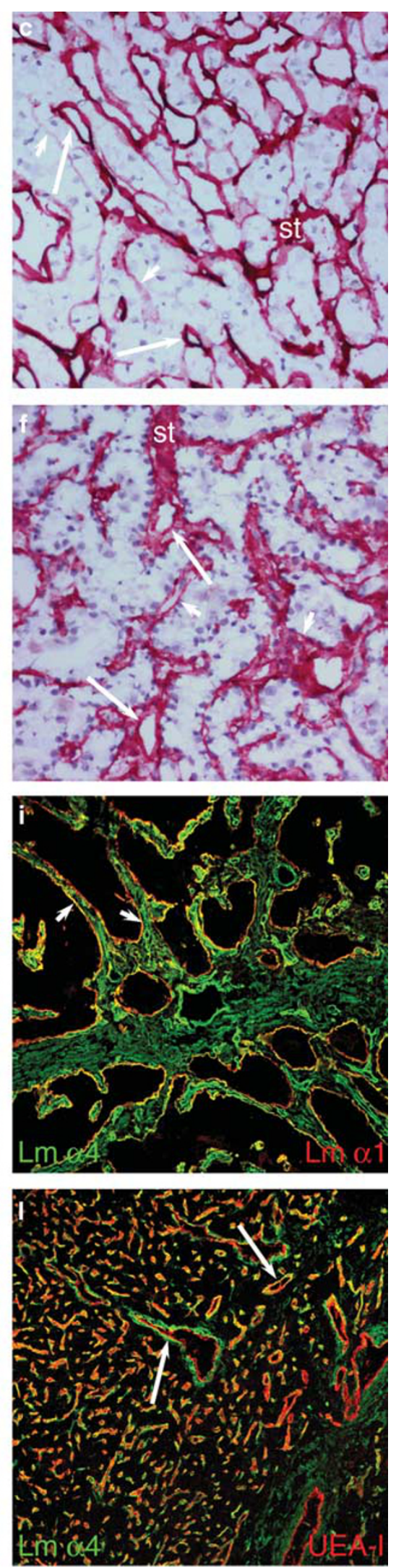
shown). When protein secretion was inhibited with monensin, Caki-1 cells showed prominent immunoreactivity for $\mathrm{Lm} \alpha 4$ chain in accumulated cytoplasmic vesicles (Figure $4 \mathrm{a}$ ),

Table 1 Distribution of $\operatorname{Lm} \alpha 4$ chain in renal tumors by double-labeling immunofluorescence microscopy

\begin{tabular}{lccc}
\hline & Stroma & BVBM & EBM \\
\hline Oncocytoma & $2 / 2$ & $2 / 2$ & $2 / 2$ \\
Grade 1 conventional RCC & $10 / 10$ & $10 / 10$ & $7 / 10$ \\
Grade 2 conventional RCC & $15 / 15$ & $15 / 15$ & $12 / 15$ \\
Grade 3 conventional RCC & $6 / 6$ & $6 / 6$ & $4 / 6$ \\
Metastases of conventional RCC & $2 / 2$ & $2 / 2$ & $2 / 2$ \\
Grade 1 papillary RCC & $2 / 2$ & $2 / 2$ & $1 / 2$ \\
& & & \\
\hline
\end{tabular}

BVBM, blood vessel endothelial BM, identified by double-labeling with TRITCUEA-I; EBM, BM of tumor cell islet, identified by double labeling with antibody against $\operatorname{Lm} \alpha 1$ chain. The number denotes the amount of tumors showing positive immunoreactivity in the specific location among all that type of tumors.
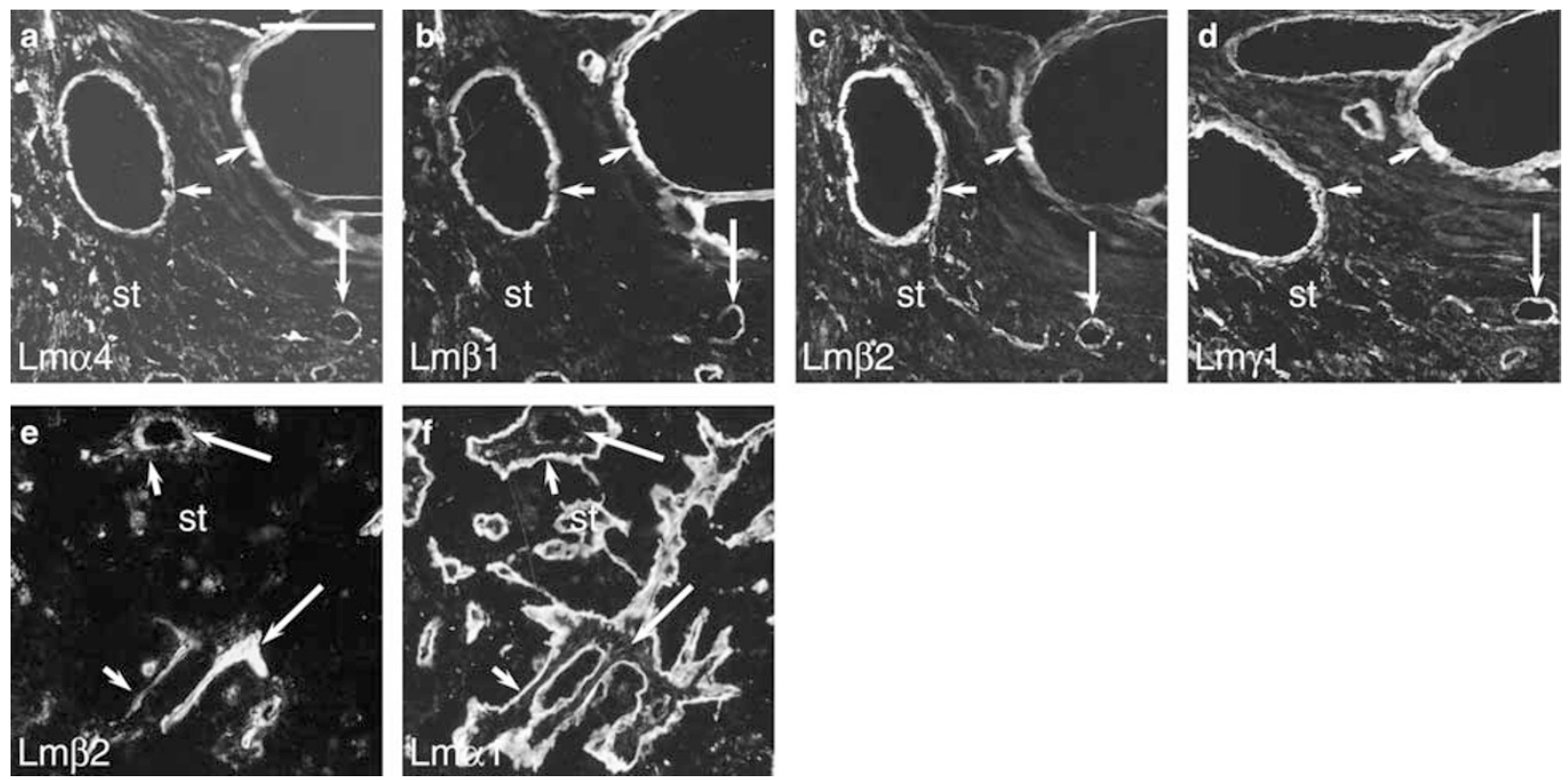

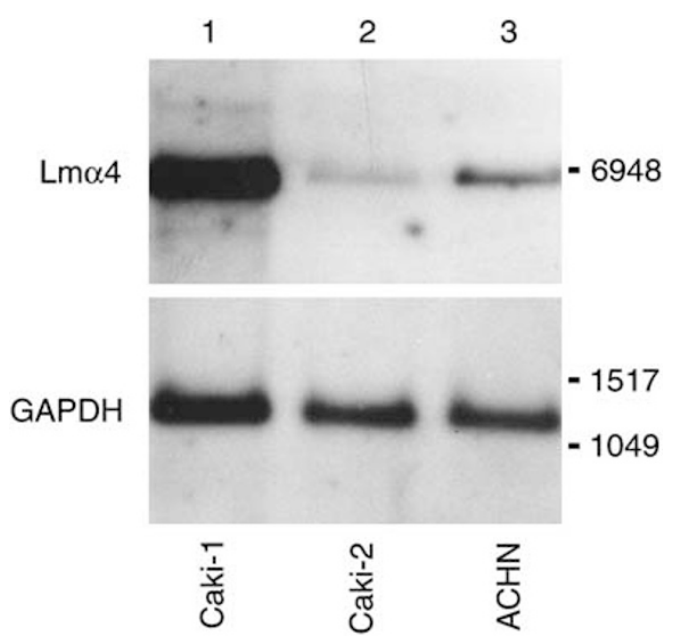

Figure 3 Northern blotting of RNA isolated from RCC cells with antisense RNA probe to $\mathrm{Lm} \alpha 4$ chain. An approximately $6.5 \mathrm{~kb}$ transcript corresponding to the size of $\mathrm{Lm} \alpha 4$ chain was detected in Caki-1 (lane 1), Caki-2 (lane 2), and ACHN (lane 3) cells. The transcript was most prominent in Caki-1 cells and weakest in Caki-2 cells. Reprobing with antisense RNA probe to GAPDH detected a transcript of approximately $1.3 \mathrm{~kb}$, which shows the loading of RNA.

Figure 2 Distribution of constituents of $\mathrm{Lm}-411$ and $\mathrm{Lm}-421$ by indirect immunofluorescence microscopy. In metastasis of grade 3 conventional RCC, immunoreactivity of $\mathrm{Lm} \alpha 4$ chain (a) was found in corresponding locations in blood vessels (long arrows), BMs of tumor cell islets (short arrows), and stroma(st), as immunoreactivity for $\operatorname{Lm} \beta 1$ (b), $\operatorname{Lm} \beta 2$ (c), and $\operatorname{Lm} \gamma 1$ (d) chains. In grade 1 papillary RCC, $\operatorname{Lm} \beta 2$ chain (e) was found in BMs of blood vessels (long arrows), but not in stroma (st) or BMs of tumor cell islets (short arrows); the latter were localized by double labeling for $\operatorname{Lm} \alpha 1$ chain (f). Scale bar, $50 \mu \mathrm{m}$.

Figure 1 Distribution of $\mathrm{Lm} \alpha 4$ chain in RCCs by immunohistochemistry with MAb FC10 and APAAP method. In oncocytoma (a) immunoreactivity for Lm $\alpha 4$ chain was found in endothelial BMs of blood vessels (long arrows) and in BM-like structures around tumor cells islets (short arrows), but only traces of immunoreactivity were detected in stroma (st) between tumor cell islets. In grade 1 (b), grade 2 (c), and grade 3 (d) conventional RCCs, grade 3 metastasis of conventional RCC (e), and grade 1 papillary RCC (f), immunoreactivity for $\mathrm{Lm} \alpha 4$ chain was found in BMs of blood vessels (long arrows) and stroma (st). The immunoreactivity of BM region around tumor cell islets (short arrows) could not be with certainty distinguished from the immunoreactivity of capillaries and stroma in most specimens. In laser scanning confocal microscopy, immunoreactivity for $\operatorname{Lm} \alpha 4$ chain (g, green) and immunoreactivity for $\operatorname{Lm} \alpha 1$ chain (h, red) were found in colocalization (i, yellow) in BMs of tumor cell islets (short arrows) in metastasis of grade 3 conventional RCC. Immunoreactivity for Lm $\alpha 4$ chain (j, green) and reactivity for TRITCUEA-I (k, red) were found in contact (I, yellow) in endothelia of blood vessels (long arrows) in grade 2 conventional RCC. Scale bar (a-f), $50 \mu$ m; (g-I), $100 \mu \mathrm{m}$. 
indicative of the synthesis of $\operatorname{Lm} \alpha 4$ chain. After monensin treatment, Caki-1 cells showed also immunoreactivity for $\mathrm{Lm}$ $\beta 1$ (Figure 4b) and $\gamma 1$ (Figure 4c) chains in cytoplasmic vesicles. On the other hand, negligible immunoreactivity was found for $\operatorname{Lm} \beta 2$ chain (Figure $4 \mathrm{~d}$ ). This suggests that these cells produce Lm-411.

Immunoprecipitation of culture medium of Caki-1 and ACHN cells with MAb 113BC7 to Lm $\gamma 1$ chain, and Western blotting of the precipitates with rabbit antiserum to $\mathrm{Lm} \alpha 4$ chain (Figure 5) showed broad bands of $M_{\mathrm{r}} 200$ 000-220 000, and a minor band of $M_{\mathrm{r}} 180$ 000. In culture medium of Caki2 cells (Figure 5), traces of proteins of $M_{\mathrm{r}} 200000-220000$ were detected. In previous studies, Western blotting of human $\operatorname{Lm} \alpha 4$ chain has shown broad bands of $M_{\mathrm{r}} 180000$ 220000 . The variability in $M_{\mathrm{r}}$ has been suggested to result from the variability of protein cleavage sites and modification of the protein by $\mathrm{N}$-glycosylation and glycosaminoglycans. ${ }^{26,53,59,60}$
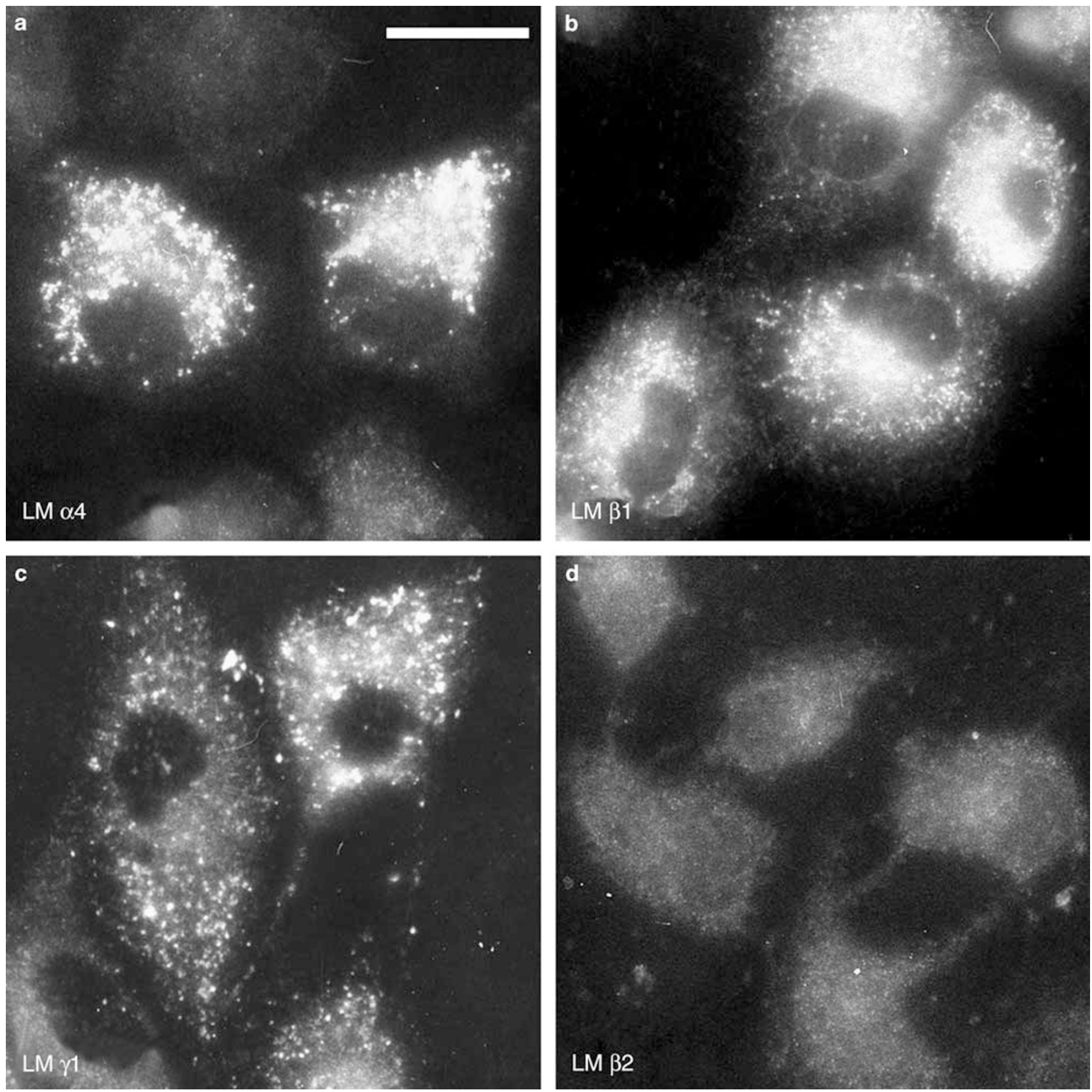

Figure 4 Immunoreactivity for Lm chains in Caki-1 cells after inhibition of protein secretion with monensin. Prominent immunoreactivity for Lm $\alpha 4$ chain (a) was found in cytoplasmic vesicles. Immunoreactivity for $\operatorname{Lm} \beta 1$ (b) and $\operatorname{Lm} \gamma 1$ (c) chains was also found in cytoplasmic vesicles, whereas negligible immunoreactivity for $\operatorname{Lm} \beta 2$ chain (d) was found in the cells. Scale bar, $10 \mu \mathrm{m}$. 


\section{Adhesion and Migration of RCCs on Recombinant} Lm-411

Lms are known to be important in cell adhesion. ${ }^{11,61}$ In order to asses the role of $\alpha 4$ chain Lms in the adhesion of carci-

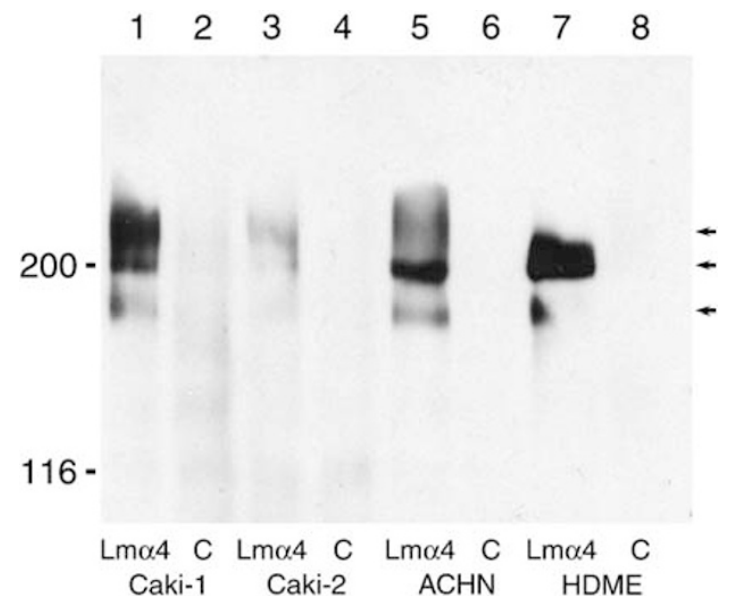

Figure 5 Production of $\mathrm{Lm} \alpha 4$ chain by RCC cells shown by immunoprecipitation of the cell culture medium with MAb $113 \mathrm{BC} 7$ against $\operatorname{Lm} \gamma 1$ chain combined with Western blotting with antiserum against $\operatorname{Lm} \alpha 4$ chain. Broad bands of $M_{\mathrm{r}} 200000-220000$ (arrows), and a minor band of $M_{\mathrm{r}}$ 180000 (arrow) were found in Caki-1 cells (lane 1). Traces of proteins of $M_{\mathrm{r}}$ 200 000-220000 were found in Caki-2 cells (lane 3). Broad bands of $M_{\mathrm{r}}$ 180000,200000 , and 220000 were found in ACHN cells (lane 5). In HDME cells (lane 7), which were used as positive controls, proteins of $M_{\mathrm{r}} 200000$ 220000 were found. Even lanes $(2,4,6,8)$ show negative controls (C), in which MAb $113 \mathrm{BC} 7$ was omitted in immunoprecipitation. noma cells, we set out to study the adhesion of Caki-2, ACHN, and Caki-1 cells to recombinant human Lm-411 and Fn by quantitative cell adhesion assay. In this assay (Figure 6), Caki-2, ACHN, and Caki-1 cells adhered significantly $(P<0.01)$ to wells coated with Fn at $1 \mu \mathrm{g} / \mathrm{ml}$. Maximal adhesion to Fn was achieved at $5 \mu \mathrm{g} / \mathrm{ml}$ coat concentration. In comparison, adhesion of RCC cells to wells coated with $1-20 \mu \mathrm{g} / \mathrm{ml}$ recombinant human $\mathrm{Lm}-411$ was negligible. When the wells were coated with the combination of $5 \mu \mathrm{g} / \mathrm{ml}$ Fn and varying concentrations of Lm-411 (Figure 7), the adhesion of Caki-1 cells to Fn was significantly $(P=0.001)$ inhibited with $5 \mu \mathrm{g} / \mathrm{ml} \mathrm{Lm}-411$. Total inhibition of adhesion was seen with $15 \mu \mathrm{g} / \mathrm{ml} \mathrm{Lm}-411$. The adhesion of Caki-2 cells to Fn was significantly inhibited with $5 \mu \mathrm{g} / \mathrm{ml} \mathrm{Lm}-411$ $(P=0.003)$, and $20 \mu \mathrm{g} / \mathrm{ml} \mathrm{Lm}-411$ diminished the adhesion over $90 \%$. Adhesion of ACHN cells to Fn was significantly inhibited with $10 \mu \mathrm{g} / \mathrm{ml} \mathrm{Lm}-411(P=0.004)$, and $20 \mu \mathrm{g} / \mathrm{ml}$ Lm-411 reduced the adhesion over $60 \%$.

Lms also play a role in cell migration. ${ }^{11,61}$ In order to see whether Lm-411 has an effect on the migration of RCC cells, we monitored undirected random migration of RCC cells on recombinant human Lm-411 and Fn, using fluorescence live cell imaging. The length of migration trajectories of all cells of representative experiments are summarized in Figure 8. In the course of $2 \mathrm{~h}$, all three RCC cells migrated significantly $(P<0.005)$ more on Lm-411 than on Fn. Caki-1 cells migrated an average of $231 \mu \mathrm{m}$ ( \pm s.d. $123 \mu \mathrm{m}$, median $216 \mu \mathrm{m})$ on recombinant Lm-411 and an average of $143 \mu \mathrm{m}$ ( \pm s.d. $98 \mu \mathrm{m}$, median $120 \mu \mathrm{m})$ on Fn. Caki-2 cells migrated an
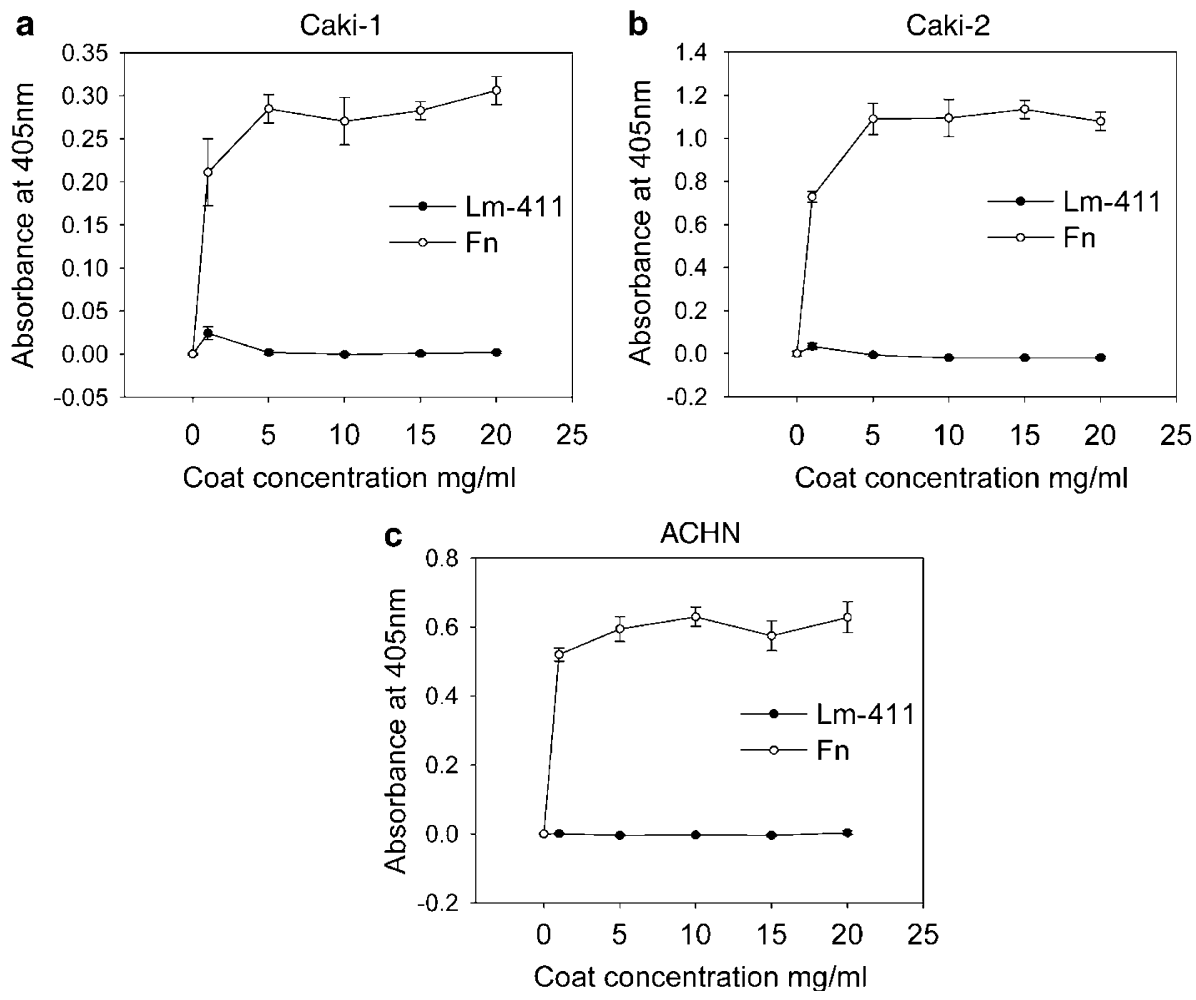

Figure 6 Adhesion of RCC cells to recombinant human $\mathrm{Lm}-411$ and $\mathrm{Fn}$ by quantitative cells adhesion assay. Caki-1 (a), Caki-2 (b), and ACHN (c) cells adhered significantly $(P<0.01)$ to wells coated with $1 \mu \mathrm{g} / \mathrm{ml} \mathrm{Fn}$, and maximal adhesion to Fn was achieved with $5 \mu \mathrm{g} / \mathrm{ml}$ coat concentration. The cells showed negligible adhesion to wells coated with $1-20 \mu \mathrm{g} / \mathrm{ml}$ recombinant human Lm-411. 
average of $200 \mu \mathrm{m}$ ( \pm s.d. $55 \mu \mathrm{m}$, median $207 \mu \mathrm{m})$ on Lm-411 and an average of $54 \mu \mathrm{m}( \pm$ s.d. $33 \mu \mathrm{m}$, median $43 \mu \mathrm{m})$ on Fn. ACHN cells migrated an average of $484 \mu \mathrm{m}( \pm$ s.d. $62 \mu \mathrm{m}$, median $480 \mu \mathrm{m})$ on Lm-411 and an average of $73 \mu \mathrm{m}$ ( \pm s.d.

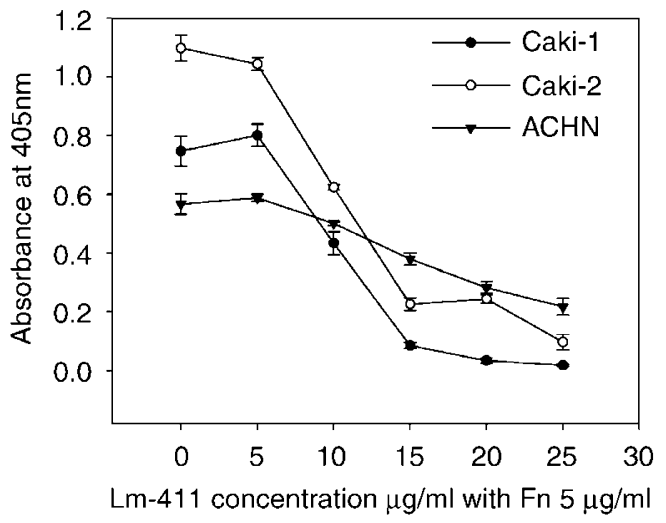

Figure 7 Adhesion of RCC to the combination of $5 \mu \mathrm{g} / \mathrm{ml} \mathrm{Fn}$ and varying concentrations of recombinant human $\mathrm{Lm}-411$ by quantitative cell adhesion assay. Adhesion of Caki-1 cells to Fn was significantly inhibited with $5 \mu \mathrm{g} / \mathrm{ml} \mathrm{Lm}-411(P=0.001)$, and over $95 \%$ inhibition was achieved with $15 \mu \mathrm{g} / \mathrm{ml} \mathrm{Lm}-411$. Adhesion of Caki-2 cells to Fn was significantly inhibited with $5 \mu \mathrm{g} / \mathrm{ml} \mathrm{Lm}-411$ ( $P=0.003)$, and over $90 \%$ inhibition was achieved with $20 \mu \mathrm{g} / \mathrm{ml} \mathrm{Lm}-411$. Adhesion of ACHN cells to Fn was significantly inhibited with $10 \mu \mathrm{g} / \mathrm{ml} \mathrm{Lm}-411(P=0.004)$, and over $60 \%$ inhibition was achieved with $20 \mu \mathrm{g} / \mathrm{ml} \mathrm{Lm}-411$.
$30 \mu \mathrm{m}$, median $66 \mu \mathrm{m}$ ) on Fn. On Lm-411, zigzag movement was pronounced when compared with the movement on Fn. During the $2 \mathrm{~h}$ imaging time, prominent movement continued for approximately $1.5 \mathrm{~h}$ (180/240 frames) on both substrata, and ceased thereafter (not shown).

\section{DISCUSSION}

The results showed that $\alpha 4$ chain Lms are present in endothelial BMs of blood vessels and stroma in all renal tumors. It was also found in the BMs of tumor cell islets in oncocytomas and most RCCs. Cultured RCC cells produced $\alpha 4$ chain Lms. Recombinant human Lm-411 did not promote adhesion of RCC cells, but inhibited the adhesion to Fn in a concentration-dependent manner. Lm-411 promoted undirected migration of RCC cells better than Fn. Thus, $\alpha 4$ chain Lms may have adhesion inhibitory function.

Recently, there have been numerous studies, in which gene expression of normal human kidney and gene expression of renal tumors, chiefly conventional (clear cell) RCCs, have been compared in gene microarray setting. In such studies, the $\operatorname{Lm} \alpha 4$ chain gene has been shown to be overexpressed in RCCs. ${ }^{15-18}$ These gene expression results have not been confirmed, however, at the protein level. Based on the comparison of $\mathrm{Lm} \alpha 4$ chain distribution in normal human kidney ${ }^{21}$ and the distribution in RCCs, shown in the present study, it is difficult to judge whether there is overexpression a

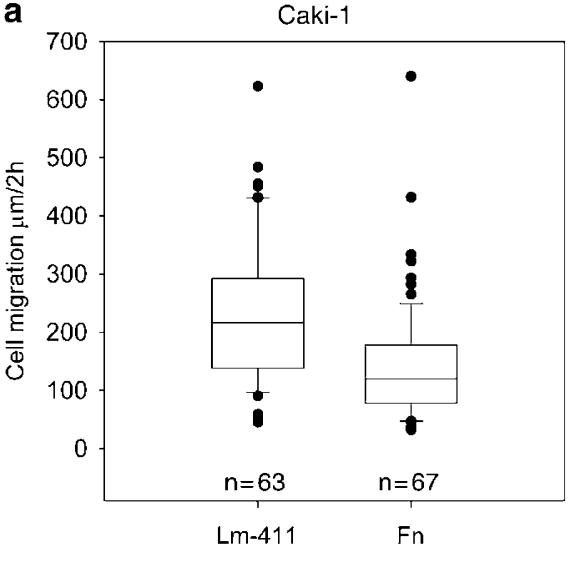

b

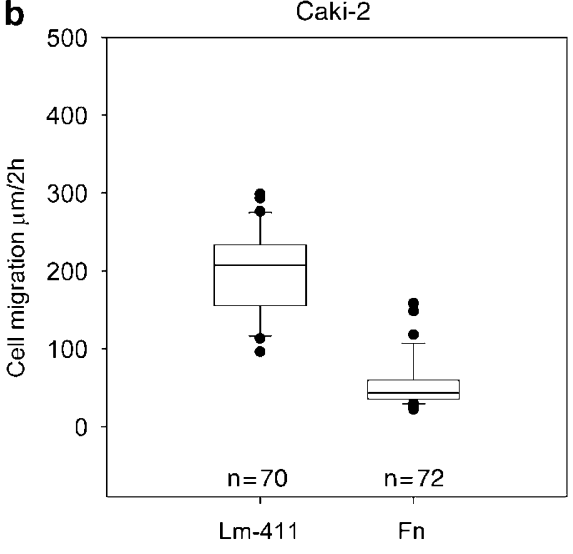

Figure 8 Box-and-whisker plots of the length of migration trajectories of all cells of representative experiments with RCC cells and recombinant human Lm-411 or Fn as migration substratum. The lower boundary of the box represents lower quartile, the line within the box represents median, and the upper boundary of the box represents upper quartile. Whiskers represent the lowest and highest expected observations. Marks outside the whiskers represent unexpected observations more than 1.5-fold interquartile range lower than the lower quartile or 1.5 -fold interquartile range higher than the higher quartile. ${ }^{70}$ Caki-1 (a), Caki-2 (b), and ACHN cells (c) migrated significantly $(P<0.005)$ more on Lm-411 than on Fn. 
at the protein level. This is due to the fact that the cell types of normal human kidney are not directly comparable to those of RCCs. Based on cytological, architectural, and immunohistochemical features it has been considered that clear cell RCCs originate from proximal tubules of nephrons. ${ }^{16,62,63}$ $\mathrm{Lm} \alpha 4$ chain is not found in proximal tubules of adult kidney, but it is found in the BM of evolving proximal tubules in developing kidney. ${ }^{21}$ Thus, our observation on the presence of $\mathrm{Lm} \alpha 4$ chain in RCCs in the BMs of tumor cell islets suggests a possibility that there is neo-expression of fetal characteristics in RCCs.

As to the putative overexpression, it is important to note that there was prominent expression of $\mathrm{Lm} \alpha 4$ chain in the vasculature and in the stroma in all renal tumors. It is known that in many tissues $\alpha 4$ chain Lms are primarily produced by mesenchyme-derived cells, including endothelial cells, blood cells, smooth muscle cells, and fibroblasts. ${ }^{20,21,26,64}$ In this regard, we suspect that the overexpression of $\operatorname{Lm} \alpha 4$ chain in RCC tissues, as suggested by microarray studies, ${ }^{15-18}$ is mostly due to its high expression in the vasculature and stroma in these tumors. It is noteworthy, however, that also RCC cells are capable of producing $\alpha 4$ chain Lms. This could reflect their assumed origin in kidney tubule epithelia, which develop from epithelial aggregates derived from condensed mesenchyme. ${ }^{65}$

In gliomas, high expression of $\mathrm{Lm} \alpha 4$ chain has been suggested to associate with increasing malignancy, tumor recurrence, and poor patient survival. ${ }^{34}$ There was no correlation, however, between $\mathrm{Lm} \alpha 4$ chain distribution and tumor grade in RCC tissues, as assessed by immunohistochemistry. In concordance, no clear correlation between Lm $\alpha 4$ chain expression and tumor grade has been detected in previous microarray studies of renal tumors. ${ }^{15-18}$

It has been suggested that there is a correlation between a shift from the expression of Lm-421 to the expression of Lm411 and the progression of malignancy in gliomas and breast carcinomas. ${ }^{33,34,38}$ In the present study, both $\operatorname{Lm} \beta 1$ and $\beta 2$ chains were found in the BMs of tumor cell islets, stroma, and the BMs of blood vessels in conventional RCCs. In papillary RCCs, Lm $\beta 1$ was found in the BMs of tumor cell islets, blood vessels, and stroma, whereas $\operatorname{Lm} \beta 2$ chain was restricted to the BMs of blood vessels. Thus, based on localization, $\mathrm{Lm} \alpha 4$ chain can be in the form of both Lm-411 and Lm-421 in RCCs, and we found no correlation between $\operatorname{Lm} \beta$ chain expression and tumor grade in RCCs. Also in previous studies by Lohi et al, ${ }^{14}$ there was no correlation between $\operatorname{Lm} \beta$ chain expression and tumor grade in RCCs.

The results on the biological functions of $\alpha 4$ chain Lms have thus far been inconclusive. For example, deletion of Lm $\alpha 4$ chain gene in mice has been suggested to both impair microvessel formation and to promote neovascularization. $^{27,28}$ Both deletion and overexpression of $\mathrm{Lm} \alpha 4$ chain gene have been suggested to promote angiogenesisrelated functions. ${ }^{28,31,32}$ On the other hand, several studies have shown that $\alpha 4$ chain Lms are relatively poor adhesion substrata. ${ }^{61,66}$ They seem to promote, however, migration of endothelial cells, blood cells, and various tumor cells, ${ }^{22,24-26,67}$ as well as transmigration of inflammatory cells through endothelium. ${ }^{8}$

Our results based on a quantitative cell adhesion assay showed that recombinant human Lm-411 counteracted the adhesion of RCC cells to Fn in a concentration-dependent manner. RCC cells migrated better on Lm-411 than on Fn, which in addition to migration-promoting activity of Lm411 could also reflect the inability of RCC cells to firmly adhere to this substratum. These results on inhibition of cell adhesion and stimulation of cell migration suggest that $\alpha 4$ chain Lms could have a role in tumor cell detachment and invasion. Such de-adhesive functions, which have been suggested to reflect intermediate state of adhesion, have previously been ascribed to matricellular proteins, such as tenascin-C and SPARC (secreted protein, acidic and rich in cystein $\left.{ }^{68,69}\right)$. In fact, $\alpha 4$ chain Lms share some properties with matricellular proteins: ${ }^{69}$ they are more abundant during development than in adult tissues, they are primarily localized to mesenchyme-derived tissues ${ }^{19-21}$ and tumor stroma, ${ }^{39}$ and deletion of $\mathrm{Lm} \alpha 4$ chain gene in mice produces a grossly normal phenotype susceptible to injury. ${ }^{27-30}$ Furthermore, $\mathrm{Lm} \alpha 4$ chain is characteristic of invasive gliomas, and inhibition of $\operatorname{Lm} \alpha 4$ chain by antisense RNA seems to prevent tumor invasion and angiogenesis. ${ }^{32,35,36} \mathrm{~A}$ similar characteristic has as also been described for SPARC. ${ }^{69}$

In summary, the results of present study show that $\alpha 4$ chain Lms are widely expressed in oncocytomas and RCCs. They are present in the tumor vasculature, stroma, and the BMs of tumor cell islets. RCC cells themselves produce $\alpha 4$ chain Lms. Recombinant human Lm-411 inhibits adhesion of RCC cells to Fn, but promotes motility of RCC cells more than Fn. The results suggest that $\alpha 4$ chain Lms have a deadhesive function, which could have relevance in clinical behavior of these tumors.

\section{ACKNOWLEDGEMENTS}

We acknowledge Professors U Wewer and D Gullberg for antibodies, as well as Mr Mika Hukkanen, Ms Pipsa Kaipainen, Mr Hannu Kamppinen, Mr Reijo Karppinen, Mr Mikko Liljeström, Ms Marja-Leena Piironen, Ms Outi Rauanheimo, Ms Anne Reijula, and Ms Hanna Wennäkoski for skillful technical assistance.

Grant numbers and sources of support: The study was supported by Helsinki University Central Hospital (EVO Grant no. TYH6269). NV was supported by The Finnish Medical Foundation.

1. Lindblad P. Epidemiology of renal cell carcinoma. Scand J Surg 2004;93:88-96.

2. Kovacs $G$, Akhtar M, Beckwith BJ, et al. The Heidelberg classification of renal cell tumours. J Pathol 1997;183:131-133.

3. Störkel S, Eble JN, Adlakha K, et al. Classification of renal cell carcinoma: Workgroup No. 1. Union Internationale Contre le Cancer (UICC) and the American Joint Committee on Cancer (AJCC). Cancer 1997;80: 987-989.

4. Delahunt B, Velickovic M, Grebe SK. Evolving classification of renal cell neoplasia. Expert Rev Anticancer Ther 2001;1:576-584.

5. Liotta LA, Kohn EC. The microenvironment of the tumour-host interface. Nature 2001;411:375-379. 
6. Ingber DE. Cancer as a disease of epithelial-mesenchymal interactions and extracellular matrix regulation. Differentiation 2002;70:547-560.

7. Jarad G, Cunningham J, Shaw AS, et al. Proteinuria precedes podocyte abnormalities inLamb2-/- mice, implicating the glomerular basement membrane as an albumin barrier. J Clin Invest 2006;116:2272-2279.

8. Sixt $M$, Engelhardt $B$, Pausch $F$, et al. Endothelial cell laminin isoforms, laminins 8 and 10, play decisive roles in T cell recruitment across the blood-brain barrier in experimental autoimmune encephalomyelitis. J Cell Biol 2001;153:933-946.

9. Yurchenco PD, Amenta PS, Patton BL. Basement membrane assembly, stability and activities observed through a developmental lens. Matrix Biol 2004;22:521-538.

10. Timpl R, Brown JC. Supramolecular assembly of basement membranes. Bioessays 1996;18:123-132.

11. Miner JH, Yurchenco PD. Laminin functions in tissue morphogenesis. Annu Rev Cell Dev Biol 2004;20:255-284.

12. Aumailley $M$, Bruckner-Tuderman $L$, Carter WG, et al. A simplified laminin nomenclature. Matrix Biol 2005;24:326-332.

13. Rissanen J, Korhonen M, Lehto VP, et al. Laminin alpha1 chain in human renal cell carcinomas and integrin-mediated adhesion of renal cell carcinoma cells to human laminin isoforms. J Pathol 2003;200: 157-167.

14. Lohi J, Tani T, Leivo I, et al. Expression of laminin in renal-cell carcinomas, renal-cell carcinoma cell lines and xenografts in nude mice. Int J Cancer 1996;68:364-371.

15. Boer JM, Huber WK, Sultmann $\mathrm{H}$, et al. Identification and classification of differentially expressed genes in renal cell carcinoma by expression profiling on a global human 31,500-element cDNA array. Genome Res 2001;11:1861-1870

16. Young AN, Amin MB, Moreno CS, et al. Expression profiling of renal epithelial neoplasms: a method for tumor classification and discovery of diagnostic molecular markers. Am J Pathol 2001;158:1639-1651.

17. Gieseg MA, Cody T, Man MZ, et al. Expression profiling of human renal carcinomas with functional taxonomic analysis. BMC Bioinformatics 2002;3:26.

18. Lenburg ME, Liou LS, Gerry NP, et al. Previously unidentified changes in renal cell carcinoma gene expression identified by parametric analysis of microarray data. BMC Cancer 2003;3:31.

19. livanainen A, Sainio K, Sariola H, et al. Primary structure and expression of a novel human laminin $\alpha 4$ chain. FEBS Lett 1995;365:183-188.

20. Lefebvre $O$, Sorokin $L$, Kedinger $M$, et al. Developmental expression and cellular origin of the laminin $\alpha 2, \alpha 4$, and $\alpha 5$ chains in the intestine. Dev Biol 1999;210:135-150.

21. Petäjäniemi N, Korhonen $M$, Kortesmaa J, et al. Localization of laminin alpha4-chain in developing and adult human tissues. J Histochem Cytochem 2002;50:1113-1130.

22. Doi $\mathrm{M}$, Thyboll J, Kortesmaa J, et al. Recombinant human laminin-10 $(\alpha 5 \beta 1 \gamma 1)$. Production, purification, and migration-promoting activity on vascular endothelial cells. J Biol Chem 2002:277:12741-12748.

23. DeHahn KC, Gonzales M, Gonzales AM, et al. The $\alpha 4$ laminin subunit regulates endothelial cell survival. Exp Cell Res 2004;294:281-289.

24. Fujiwara H, Gu J, Sekiguchi K. Rac regulates integrin-mediated endothelial cell adhesion and migration on laminin-8. Exp Cell Res 2004;292:67-77.

25. Pedraza C, Geberhiwot T, Ingerpuu S, et al. Monocytic cells synthesize, adhere to, and migrate on laminin-8 ( $\alpha 4 \beta 1 \gamma 1)$. J Immunol 2000;165:5831-5838.

26. Geberhiwot T, Assefa D, Kortesmaa J, et al. Laminin-8 ( $\alpha 4 \beta 1 \gamma 1)$ is synthesized by lymphoid cells, promotes lymphocyte migration and costimulates T cell proliferation. J Cell Sci 2001;114:423-433.

27. Thyboll J, Kortesmaa J, Cao R, et al. Deletion of the laminin alpha4 chain leads to impaired microvessel maturation. Mol Cell Biol 2002;22:1194-1202.

28. Zhou Z, Doi M, Wang J, et al. Deletion of laminin-8 results in increased tumor neovascularization and metastasis in mice. Cancer Res 2004:64:4059-4063.

29. Wallquist W, Plantman S, Thams $S$, et al. Impeded interaction between Schwann cells and axons in the absence of laminin alpha4. J Neurosci 2005;25:3692-3700.

30. Wang J, Hoshijima M, Lam J, et al. Cardiomyopathy associated with microcirculation dysfunction in laminin alpha4 chain-deficient mice. J Biol Chem 2006;281:213-220.
31. Li J, Zhou L, Tran HT, et al. Overexpression of laminin-8 in human dermal microvascular endothelial cells promotes angiogenesis-related functions. J Invest Dermatol 2006;126:432-440.

32. Fujita $M$, Khazenzon NM, Ljubimov AV, et al. Inhibition of laminin-8 in vivo using a novel poly(malic acid)-based carrier reduces glioma angiogenesis. Angiogenesis 2006;9:183-191.

33. Ljubimova JY, Lakhter AJ, Loksh A, et al. Overexpression of alpha4 chain-containing laminins in human glial tumors identified by gene microarray analysis. Cancer Res 2001;61:5601-5610.

34. Ljubimova JY, Fugita M, Khazenzon NM, et al. Association between laminin-8 and glial tumor grade, recurrence, and patient survival. Cancer 2004:101:604-612.

35. Khazenzon NM, Ljubimov AV, Lakhter AJ, et al. Antisense inhibition of laminin-8 expression reduces invasion of human gliomas in vitro. Mol Cancer Ther 2003;2:985-994.

36. Nagato $\mathrm{S}$, Nakagawa $\mathrm{K}$, Harada $\mathrm{H}$, et al. Downregulation of laminin alpha4 chain expression inhibits glioma invasion in vitro and in vivo. Int J Cancer 2005;117:41-50.

37. Lee BS, Fujita M, Khazenzon NM, et al. Polycefin, a new prototype of a multifunctional nanoconjugate based on poly(beta-L-malic acid) for drug delivery. Bioconjug Chem 2006;17:317-326.

38. Fujita M, Khazenzon NM, Bose $\mathrm{S}$, et al. Overexpression of beta1-chain-containing laminins in capillary basement membranes of human breast cancer and its metastases. Breast Cancer Res 2005;7:R411-R421.

39. Määttä $M$, Bützow R, Luostarinen J, et al. Differential expression of laminin isoforms in ovarian epithelial carcinomas suggesting different origin and providing tools for differential diagnosis. J Histochem Cytochem 2005;10:1293-1300.

40. Korhonen $M$, Laitinen $L$, Ylänne J, et al. Integrin distributions in renal cell carcinomas of various grades of malignancy. Am J Pathol 1992;141:1161-1171.

41. Thoenes W, Storkel S, Rumpelt HJ. Histopathology and classification of renal cell tumors (adenomas, oncocytomas and carcinomas). The basic cytological and histopathological elements and their use for diagnostics. Pathol Res Pract 1986;181: $125-143$

42. Mostofi FK, Davis CJ. Histological Typing of Kidney Tumours. International Histological Classification of Tumours. WHO, 2nd edn. Springer: Geneva, 1998

43. Korhonen $M$, Sariola $H$, Gould VE, et al. Integrins and laminins in human renal carcinoma cells and tumors grown in nude mice. Cancer Res 1994;54:4532-4538.

44. Virtanen I, Lohi J, Tani T, et al. Distinct changes in the laminin composition of basement membranes in human seminiferous tubules during development and degeneration. Am J Pathol 1997;150:1421-1431.

45. Wewer UM, Thornell LE, Loechel F, et al. Extrasynaptic location of laminin beta 2 chain in developing and adult human skeletal muscle. Am J Pathol 1997:151:621-631.

46. Määttä $M$, Virtanen I, Burgeson R, et al. Comparative analysis of the distribution of laminin chains in the basement membranes in some malignant epithelial tumours: the alpha1 chain of laminin shows a selected expression pattern in human carcinomas. J Histochem Cytochem 2001;49:711-726.

47. Tiger CF, Champliaud MF, Pedrosa-Domellof F, et al. Presence of laminin alpha5 chain and lack of laminin alpha1 chain during human muscle development and in muscular dystrophies. J Biol Chem 1997:272:28590-28595.

48. Holthöfer H, Virtanen I, Kariniemi AL, et al. Ulex europaeus I lectin as a marker for vascular endothelium in human tissues. Lab Invest 1982;47:60-66.

49. Tartakoff AM. Perturbation of vesicular traffic with the carboxylic ionophore monensin. Cell 1983;32:1026-1028.

50. Kortesmaa J, Yurchenco P, Tryggvason K. Recombinant laminin-8 $(\alpha 4 \beta 1 \gamma 1)$, Production, purification, and interactions with integrins. J Biol Chem 2000;275:14853-14859.

51. livanainen A, Kortesmaa J, Sahlberg C, et al. Primary structure, developmental expression, and immunolocalization of the murine laminin $\alpha 4$ chain. J Biol Chem 1997;272:27862-27868.

52. Prater CA, Plotkin J, Jaye $D$, et al. The properdin-like type I repeats of human thrombospondin contain a cell attachment site. J Cell Biol 1991;112:1031-1040. 
53. Kortesmaa J, Doi M, Patarroyo $M$, et al. Chondroitin sulphate modification in the alpha4 chain of human recombinant laminin-8 (alpha4beta1gamma1). Matrix Biol 2002;21:483-486.

54. Engvall $E$, Ruoslahti $E$. Binding of soluble form of fibroblast surface protein, fibronectin, to collagen. Int J Cancer 1977;20:1-5.

55. Clark RA, Folkvord JM, Nielsen LD. Either exogenous or endogenous fibronectin can promote adherence of human endothelial cells. J Cell Sci 1986;82:263-280.

56. Entschladen F, Drell IV TL, Lang K, et al. Analysis methods of human cell migration. Exp Cell Res 2005;307:418-426.

57. Klopfenstein DR, Vale RD. The lipid binding pleckstrin homology in UNC-104 kinesin is necessary for synaptic vesicle transport in the Caenorhabditis elegans. Mol Biol Cell 2004;15:3729-3739.

58. Virtanen I, Gullberg D, Rissanen J, et al. Laminin alpha1-chain shows a restricted distribution in epithelial basement membranes of fetal and adult human tissues. Exp Cell Res 2000;257:298-309.

59. Talts JF, Sasaki T, Miosge N, et al. Structural and functional analysis of the recombinant $\mathrm{G}$ domain of the laminin alpha4 chain and its proteolytic processing in tissues. J Biol Chem 2000;275:35192-35199.

60. Hayashi $\mathrm{Y}$, Kim K-H, Fujiwara $\mathrm{H}$, et al. Identification and recombinant production of human laminin alpha4 subunit splice variants. Biochem Biophys Res Commun 2002;299:498-504.

61. Patarroyo M, Tryggvason K, Virtanen I. Laminin isoforms in tumor invasion, angiogenesis and metastasis. Semin Cancer Biol 2002;12: 197-207.
62. Thoenes W, Storkel S, Rumpelt HJ, et al. Cytomorphological typing of renal cell carcinoma - a new approach. Eur Urol 1990;18(Suppl 2):6-9.

63. Lohi J, Leivo I, Oivula J, et al. Extracellular matrix in renal cell carcinomas. Histol Histopathol 1998;13:785-796.

64. Pierce RA, Griffin GL, Mudd MS, et al. Expression of laminin $\alpha 3, \alpha 4$, and $\alpha 5$ chains by alveolar epithelial cells and fibroblasts. Am J Respir Cell Mol Biol 1998:19:237-244.

65. Kanwar YS, Wada J, Lin S, et al. Update of extracellular matrix, its receptors, and cell adhesion molecules in mammalian nephrogenesis. Am J Physiol Renal Physiol 2004;286:202-215.

66. Nishiuchi R, Takagi J, Hayashi $M$, et al. Ligand-binding specificities of laminin-binding integrins: a comprehensive survey of laminin-integrin interactions using recombinant $\alpha 3 \beta 1, \alpha 6 \beta 1, \alpha 7 \beta 1$ and $\alpha 6 \beta 4$ integrins. Matrix Biol 2006;25:189-197.

67. Fujiwara H, Kikkawa $Y$, Sanzen N, et al. Purification and characterization of human laminin-8:laminin-8 stimulates cell adhesion and migration through $\alpha_{3} \beta_{1}$ and $\alpha_{6} \beta_{1}$ integrins. J Biol Chem 2001;276: 17550-17558.

68. Murphy-Ullrich JE. The de-adhesive activity of matricellular proteins: is intermediate cell adhesion an adaptive state? J Clin Invest 2001;107:785-790.

69. Bornstein P, Sage EH. Matricellular proteins: extracellular modulators of cell function. Curr Opin Cell Biol 2002;14:608-616.

70. Tukey JW. Exploratory Data Analysis. Addison-Wesley: Reading, MA, 1977. 